\title{
Impact of Adding Rumen Protected Lysine or/and Methionine on Some Wool Characteristics in Barki Sheep \\ Ramadan, W. A. ${ }^{1}$; M. A. El-Harairy ${ }^{2}$; W. A. Khalil ${ }^{2}$ and Alaa H. Youssef ${ }^{1}$ \\ ${ }^{1}$ Wool Production and Technology Department, Animal and Poultry Production Division, Desert Research Center. \\ ${ }^{2}$ Animal Production Department, Faculty of Agriculture, Mansoura University.
}

\section{ABSTRACT}

Twenty four adult Barki eweswere used to investigate the effect of addition of rumen protected amino acids, lysine or/and methionineon some wool characteristics. This study was carried out from September 2016 to February 2017. Animals were divided into four groups (6ewes/group). The first group (Control): fed only the control diet, second group (LYS): fed the control diet and rumen protected lysine (6g Lysi pearl $/ \mathrm{kg}$ concentrate, $3 \mathrm{~g} /$ animal/day), third group (MET): fed the control diet and rumen protected methionine (14g Smartamin/kg concentrate, $7 \mathrm{~g} / \mathrm{animal} / \mathrm{day})$ and fourth group (LYS+MET): fed the control diet and mixture of ( $3 \mathrm{~g}$ LYS and $7 \mathrm{~g}$ MET/animal/day) for six months. Some wool measurements were investigated such as fiber length, fiber diameter, staple strength and wool growth per $10 \mathrm{~cm}^{2}$ and clean wool yield. Results showed that supplementing methionine caused significant $(\mathrm{P}<0.05)$ increase in fiber length, fiber diameter, staple strength and clean wool yield. Lysine increased fiber length significantly $(\mathrm{P}<0.05)$, but did not affect clean wool yield and caused small increase in both staple strength and fiber diameter. Supplementing of (mixture of methionine and lysine) increased significantly fiber length, wool yield and staple strength, but caused insignificant increase in clean wool production per $10 \mathrm{~cm}^{2}$, but had no significant effect on fiber diameter.From these results, it can be concluded that addition of rumen protected methionine (7g Smartamin/animal/day) forsix monthsenhanced significantly wool characteristics of Barki ewes (fiber length, fiber diameter, staple strength and clean wool yield).

Keywords: Sheep, lysine,methionine,wool characteristics,amino acids.

\section{INTRODUCTION}

It is known thatfiber growth rate and its composition can be influenced by the availability of the amino acids which contain Sulphur to the follicle and a high proportion of the high-sulphur amino acids cysteine (Corbett 1979). In this respect, Graceva (1969)stated that wool growth increased by 17.9, 33.7 and $42.2 \%$ above basal when $3 \mathrm{~g} /$ animal / day of methionine was given orally, subcutaneously or infused into the abomasum, respectively. Bird and Moir (1972) observed an increasing the wool growth in sheep above the controls, when methionine was continuously infused ruminally or abomasally, respectively.

Lysine plays an important role for proteins synthesis in the inner root sheath, the area of the follicle of fiber where the growth of fiber is initiated (Rogers 1964). The importance of lysine for fiber growth may be related to its high content in his tone proteins which are active in cell division (Busch 2012). Recently, the increase of the population in Egypt and the expansion of Egyptian wool industry have led to increasing the demand for wool textile and hence the raw wool. This has created a great necessity to make studies for improving the wool produced locally to standardize the manufacturing needs to produce woolen textiles satisfying the consumer's taste and decreasing the imported expensive wool.

Therefore, aim of this study was to investigate the effect of addition of rumen protected amino acids, lysine or/and methionine on some wool characteristics in Barki sheep.

\section{MATERIALS AND METHODS}

The present study was conducted at Maryout Research Station, belonging to Desert Research Center, Ministry of Agriculture and Land Reclamation (Latitude $31.02^{\circ} \mathrm{N}$, longitude $29.80^{\circ} \mathrm{E}$ ) located $35-\mathrm{km}$ south-west of Alexandria. The experiment was carried out from September 2016 to February 2017.
Animals:

Total of 24 Barki adult ewes (non pregnant) were used in this study. Age of ewes ranged between 3 and 4 years and average live body weight was $28.95 \pm 1.37 \mathrm{~kg}$. The experimental animals were healthy and free from diseases. They were fed on Berseem hay (Trifoliumalexandrinum), offered ad. libitum plus concentrate feed mixture $(14 \% \mathrm{CP}$ and $60 \% \mathrm{TDN}$ ) at a rate of $1 / 2 \mathrm{~kg} /$ ewe/day, which was composed of cottonseed cake $50 \%$, wheat bran $18 \%$, yellow corn $15 \%$, rice polish $11 \%$, molasses $3 \%$, limestone $2 \%$ and common salt, $1 \%$. Drinking water was provided twice daily.

\section{Experimental design:}

The study included four groups of Barki adult ewes (6 ewes/group). The first group (Control): fed only the control diet, second group (LYS): fed the control diet and rumen protected lysine (6gLysi pearl $/ \mathrm{kg}$ concentrate, $3 \mathrm{~g}$ /animal/day), third group (MET): fed the control diet and rumen protected methionine (14g Smartamin / $\mathrm{kg}$ concentrate, $7 \mathrm{~g}$ /animal/day) and fourth group (LYS+MET): fed the control diet and mixture of $3 \mathrm{gLYS}$ and $7 \mathrm{gMET} / \mathrm{animal} /$ day). The rumen protected amino acids in this experiment were imported from United Biomed Egypt.

\section{Wool characteristics:}

Wool samples were harvested from patch (10 $\mathrm{cm} 2$ ) located in the left mid-side position of each ewe at December (after 3 months) and from right side position at February (after 6 months, end of treatments)to record wool measurements as the following:

Fiber length (FL):

Average lengths of ten fibers taken randomly from each greasy sample were estimated by using a rule to the nearest $0.5 \mathrm{~cm}$. The length was taken as the distance between the beginning and the end of each fiber.

\section{Fiber diameter (FD):}

Short sections of approximately 400 fibers were prepared and put in paraffin oil on glass slides and covered with glass cover. Fiber diameter was measured by using a microscope and image captured by image analysis software (Zen, 2012, Blue edition) and (device Carl-Zeiss 
micro-imaging) with lenses $10 / 0.847$. Average diameter of fiber and standard error for each sample were calculated.

Clean wool yield:

In order to calculate wool yield, each collected greasy wool samples was scoured using 4 bowls scouring machine. The liquor in the bowls was heated electrically with thermostat control to adjust the temperature in each bowl. Temperature in the first three was $50^{\circ} \mathrm{C}$ while it was $45^{\circ} \mathrm{C}$ in the fourth bowl. Scouring liquor had $1 \%$ soap and $1 \%$ soda ash $\left(\mathrm{Na}_{2} \mathrm{CO}_{3}\right)$ (Chapman, 1960). Samples were passed from bowl to another through a hand squeezer. The hand squeezers were used to return back the scouring liquor to the previous bowls. Samples were preliminary dried by centrifuged dryer. Then fleeces were dried in a ventilated oven at $105{ }^{\circ} \mathrm{C}$ and the yield percentage was estimated on a standard basis allowing only $14 \%$ residual matter. Both greasy and clean wool weight were recorded for each sample. A method suggested by Chapman (1960) was used to determine the weight of clean wool for every sample as follows:

Weight of clean scoured and dry wool (grams) Clean scoured yield $(\%)=$ Greasy wool weight (grams)

\section{Staple strength (SS):}

Staple strength is calculating the force which is required for breaking the staple in Newton and dividing that value by staple thickness (Newton in kilotex, N/Ktex). Ten staples have been taken randomly from each greasy sample to be prepared to measure their strength using the Agritest Staple Breaker (Caffin, 1980).

\section{Amino acids analysis in wool:}

Acid hydrolyzed amino acid by amid bond breakage were determined according to Pellet and Young(1980) as follows:Diethyl ether was used for defatting $1 \mathrm{~g}$ from each dry wool sample. Five $\mathrm{ml}$ of $6 \mathrm{~N}$ hydrochloric acid was used to hydrolyze $0.4 \mathrm{~g}$ in evacuated sealed test tube made of pyrex at $110^{\circ} \mathrm{C}$ for 24 hours. Hydrolysate was transferred to containers quantitavely at the end of the period. Hydrochloric acid was evaporated on water bath at $50-60^{\circ} \mathrm{C}$ to dryness. Five $\mathrm{ml}$ of distilled water was added to the hydrolysate and then evaporated to dryness to get rid of the excess of hydrochloric acid. Distilled water was added again until the excess of the hydrochloric acid removed completely. Samples were dried for obtaining dry film. The dry film that was obtained was dissolved in a known volume of sample dilution buffer $(0.1 \mathrm{~N}$ sodium acetate buffer, $\mathrm{pH}$ 2.2). Membrane filter $0.22 \mu \mathrm{m}$ was used to filter the solution. The samples were stored in freezer in sealed vials until fractionation of the amino acid by using the amino acid analyzer (Sykam Clarity Amino Acid Analyzer SW, Central Lab of Desert Research Center).

\section{Statistical Analysis:}

SAS (2008) program, utilizing GLM procedure was used to analyze the obtained data and the differences between each two means within each factor were compared using Duncan Multiple Range Test (Duncan, 1955).

\section{RESULTS AND DISCUSSION}

Fiber length of wool:

Results presented in Figure (1) showed that fiber length significantly $(\mathrm{P}<0.05)$ increased by supplementing methionine, lysine and mixture of methionine and lysine compared with control. Furthermore, the fiber length was higher in all treatments after 6 months compared with 3 months of experiment. Our results are in agreement with several authors (Reis and Tunks, 1978; Reis et al., 1991), who found that the omission of methionine from a mixture of amino acids reduced wool growth and decreased length growth rate. Methionine has specific effects on wool growth, it may be related to the formation of S-adenosyl-Lmethionine. This compound is a methyl donor for many important reactions which may influence wool growth (Reis 1982). It is also an intermediate in the biosynthesis of the polyamines, spermidine and spermine, which appear to have a role in nucleic acid and protein synthesis, especially in actively dividing tissues (Tabor and Tabor 1976; WilliamsAshman and Canellakis 1979).

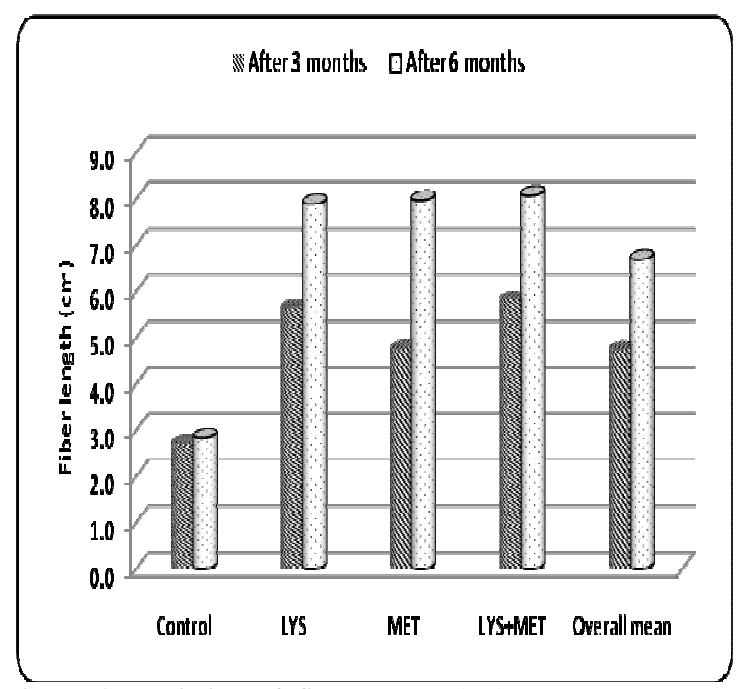

Figure 1. Variation of fiber length $(\mathrm{cm})$ among treatments during 3 and 6 months interval.

In the same way, Reis (1991) also indicated a large effect of lysine intake on the rate of wool growth of preruminant lambs receiving all their nutrients via the abomasum. Sahlu and Fernandez (1992) found that there was a large increase in fiber length with infusion of $2 \mathrm{~g}$ of lysine per day. Lysine plays an important role for wool growth, this role may be partly related to the high content of lysine in histone proteins, which are important for cell division, and inner root sheath proteins (Reis, 1989). On the other hand, Reis and Tunks (1978) observed that wool fiber length decreased when lysine was added to a lysine deficient diet. While, Sahlu and Fernandez (1992) stated that average growth rate of wool fiber length decreased significantly when infused lysine and methionine together than the average of each amino acid infused individually. Infusion of both methionine and lysine into the abomasum resulted in increasing wool growth rate, suggesting that methionine may be the first (Doyle and Bird, 1975) and lysine the second limiting amino acid (Storm and Orskov, 1984) in wool growth. 


\section{Wool fiber diameter:}

Addition of rumen protected amino acids tended to make a slight increase in fiber diameter especially with lysine and lysine with methionine compared with control group $(31.07 \mu \mathrm{m}, 31.93 \mu \mathrm{m}$ and $29.34 \mu \mathrm{m}$, respectively). Data in Figure, (2) showed that Supplementation with methionine leads to significant increase in fiber diameter $(37.39 \mu \mathrm{m})$ compared with other groups. Our results are in agreement with Sahlu and Fernandez(1992), who reported that infusion of methionine increased fiber diameter and mixture of lysine and methionine had no significant effect on fiber diameter. Galbraith (2000) stated that the increased diameter of Mohair fibers following methionine supplementation is due to the suggested role of an increased intermediate filament-associated protein fraction in producing a greater volume of cells of the hair cortex. In addition, methionine performed some specific function, perhaps in wool protein synthesis or cell division according to Reis et al. (1990).In this line, Reis and Tunks (1978) and Reis et al., (1990) also stated that the omission of methionine from a mixture of amino acids decreased fiber diameter.

Clean wool production per $10 \mathrm{~cm} 2$ and yield \%:

Data in Table (1) revealed that addition of methionine resulted significantly $(\mathrm{P}<0.05)$ in higher of clean wool production per $10 \mathrm{~cm} 2$ compared with the other groups, whereas addition of lysine and both methionine and lysine groups had an increase compared with control group. Increase in fiber diameter and fiber length are the reason for the increase happened by methionine supplementation. Stephenson et al., (1991) found that methionine tended to increase wool productivity.
Moreover, Infusion of methionine tended to increase wool production by $20 \%$ compared with the control group (Helal, 2004). Clean wool yield takes the same trend of clean wool per studied area. In the same way, Galbraith (2000) reported that methionine stimulated raw fiber yields of both Angora and Cashmere goats. Sahlu and Fernandez (1992) revealed that grease and clean mohair yields were increased with methionine infusion. The same results conducted with sheep were reported by many authors (Reis, 1967; Williams, et al., 1972; Reis et al., 1973).

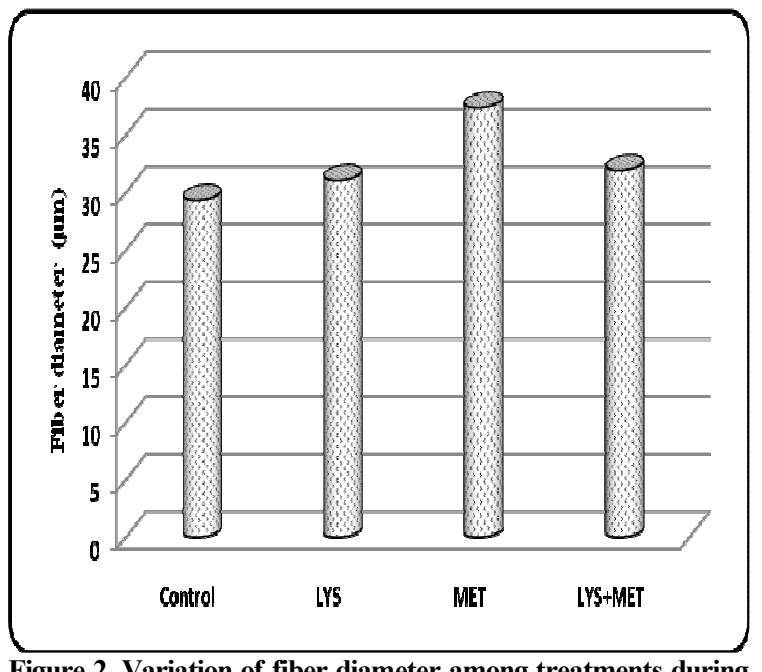

Figure 2. Variation of fiber diameter among treatments during 6 months interval.

Table 1. Effect of addition rumen protected amino acids on some wool characteristics of Barki ewes (LSM \pm SE) at the end of treatment.

\begin{tabular}{lcccc}
\hline $\begin{array}{l}\text { Treatment } \\
\text { Measurement }\end{array}$ & Control & LYS & MET & LYS+MET \\
\hline Clean wool production per $10 \mathrm{~cm}^{2}$ & $5.86+0.59^{\mathrm{b}}$ & $7.29+0.54^{\mathrm{b}}$ & $8.31+0.54^{\mathrm{a}}$ & $7.13+0.54^{\mathrm{b}}$ \\
Wool yield (\%) & $55.48 \pm 2.15^{\mathrm{b}}$ & $54.66 \pm 2.15^{\mathrm{b}}$ & $64.25 \pm 2.15^{\mathrm{a}}$ & $58.53 \pm 2.15^{\mathrm{ab}}$ \\
Staple strength N/Ktex & $30.98 \pm 1.9^{\mathrm{c}}$ & $34.24 \pm 1.91^{\mathrm{ab}}$ & $42.67 \pm 1.91^{\mathrm{a}}$ & $36.66 \pm 1.91^{\mathrm{b}}$ \\
\hline
\end{tabular}

Mean values with similar superscripts within the same row are not significantly different.

\section{Stable strength:}

Data in Table (1) show that the staple strength increased significantly $(\mathrm{P}<0.05)$ by adding methionine or lysine and methionine compared with control. Whereas, addition of lysine did not cause significant effect on staple strength. Likewise, the supplementation of low and high methionine by intraperitoneal injection increased staple strength significantly as reported by Bray et al, (1993). Moreover, Hyndet al (2015) revealed that the omission of methionine from the mixture consistently reduced staple strength.

\section{Wool content of amino acids:}

Data presented in table (2) showed that adding rumen protected amino acids lysine or/and methionine caused a significant $(\mathrm{P}<0.05)$ increase in lysine, serine, glutamic acid and tyrosine, while it caused significant $(\mathrm{P}<0.05)$ decrease in methionine, glycine, valine, leucine, proline and ammonia compared to the control group.

This modification seems to be due entirely to an alteration in the overall composition of the high-sulfur proteins and to an increase in their proportion in the fiber.
These variations are not the result of a change in the composition of individual proteins, but are due to alterations in their relative proportions and to the initiation of the synthesis of new proteins, many of which are extremely rich in cystine. It is suggested that the heterogeneity of the high-sulfur proteins may be due, in part, to similar changes in composition caused by natural variations in the nutrition of sheep. This is agreement with Gilespieet al. (1969), who stated that when the diet of sheep is supplemented by the infusion of sulfurcontaining amino acids into the abomasum, there were changes in amino acid composition of wool, with significant increases in cystine, histidine, threonine, serine and proline. There were decreases in the contents of aspartic acid, leucine and phenylalanine. These differences would be consistent with a simple increase in the proportion of high sulphur proteins in wool after sulphur-enrichment, for high-sulphur proteins, compared with low sulfur proteins, show variations in composition of the same kind, namely a higher content of Scarboxymethylcysteine, histidine, threonine, serine and 
proline and a lower content of aspartic acid, leucine and phenylalanine. In the present study, it was observed that proline decreased significantly. Responses could differ with environmental conditions, the basal diets, doses of amino acids and the methods of giving amino acids for the animal. The difference in responses needs further studies.

Table 2. Effect of addition of rumen protected amino acids on wool content of amino acids (\%) in Barki ewes

\begin{tabular}{lcccc}
\multicolumn{1}{c}{$(\mathbf{L S M} \pm \mathbf{S E ) .}$} & \multicolumn{3}{c}{ MET } & LYS+MET \\
\hline Treatment & Control & LYS & $5.10 \pm 0.29^{\mathrm{a}}$ & $4.80 \pm 0.28^{\mathrm{ab}}$ \\
\hline Lysine & $3.20 \pm 0.04^{\mathrm{c}}$ & $4.30 \pm 0.25^{\mathrm{b}}$ & $6.60 \pm 0.38$ & $6.14 \pm 0.35$ \\
Cysteine & $6.13 \pm 0.21$ & $6.84 \pm 0.39$ & $0.30 \pm 0.02^{\mathrm{bc}}$ & $0.28 \pm 0.02^{\mathrm{c}}$ \\
Methionine & $0.37 \pm 0.01^{\mathrm{a}}$ & $0.34 \pm 0.02^{\mathrm{b}}$ & $7.20 \pm 0.42$ & $7.10 \pm 0.41$ \\
Asparagine & $7.41 \pm 0.11$ & $7.23 \pm 0.42$ & $5.70 \pm 0.33$ & $5.60 \pm 0.32$ \\
Threonine & $5.95 \pm 0.07$ & $5.82 \pm 0.33$ & $10.12 \pm 0.58^{\mathrm{ab}}$ & $10.62 \pm 0.61^{\mathrm{a}}$ \\
Serine & $9.04 \pm 0.04^{\mathrm{b}}$ & $10.46 \pm 0.61^{\mathrm{a}}$ & $19.26 \pm 1.11^{\mathrm{a}}$ & $19.40 \pm 1.12^{\mathrm{a}}$ \\
Glutamic & $15.02 \pm 0.16^{\mathrm{b}}$ & $19.73 \pm 1.14^{\mathrm{a}}$ & $4.82 \pm 0.28^{\mathrm{b}}$ & $4.80 \pm 0.28^{\mathrm{b}}$ \\
Glycine & $5.65 \pm 0.12^{\mathrm{a}}$ & $5.10 \pm 0.29^{\mathrm{ab}}$ & $4.73 \pm 0.27$ & $4.90 \pm 0.28$ \\
Alanine & $4.55 \pm 0.06$ & $5.20 \pm 0.30$ & $3.60 \pm 0.21^{\mathrm{b}}$ & $3.40 \pm 0.20^{\mathrm{b}}$ \\
Valine & $4.44 \pm 0.13^{\mathrm{a}}$ & $3.60 \pm 0.21^{\mathrm{b}}$ & $3.12 \pm 0.18$ & $2.70 \pm 0.16$ \\
Isoleucine & $2.76 \pm 0.10$ & $2.90 \pm 0.17$ & $7.32 \pm 0.42^{\mathrm{b}}$ & $7.10 \pm 0.41^{\mathrm{b}}$ \\
Leucine & $8.05 \pm 0.10^{\mathrm{a}}$ & $6.94 \pm 0.40^{\mathrm{ab}}$ & $5.30 \pm 0.31^{\mathrm{bc}}$ & $6.60 \pm 0.38^{\mathrm{a}}$ \\
Tyrosine & $4.62 \pm 0.15^{\mathrm{c}}$ & $6.10 \pm 0.35^{\mathrm{a}} \mathrm{b}$ & $3.20 \pm 0.18$ & $2.90 \pm 0.17$ \\
Phenylalanine & $3.01 \pm 0.09$ & $2.86 \pm 0.17$ & $2.60 \pm 0.15$ & $2.40 \pm 0.14$ \\
Histidine & $2.81 \pm 0.14$ & $2.80 \pm 0.16$ & $5.10 \pm 0.29$ & $5.30 \pm 0.31$ \\
Arginine & $5.69 \pm 0.63$ & $5.20 \pm 0.30$ & $3.88 \pm 0.23^{\mathrm{b}}$ & $4.21 \pm 0.24^{\mathrm{b}}$ \\
Proline & $6.57 \pm 0.11^{\mathrm{a}}$ & $3.30 \pm 0.19^{\mathrm{c}}$ & $2.05 \pm 0.12^{\mathrm{b}}$ & $1.75 \pm 0.10^{\mathrm{b}}$ \\
Ammonia & $4.75 \pm 0.08^{\mathrm{a}}$ & $1.28 \pm 0.08^{\mathrm{c}}$ & &
\end{tabular}

Mean values with similar superscripts within the same row are not significantly different.

\section{CONCLUSION}

In conclusion, addition of rumen protected methionine (7g Smartamin /head /day) for 6 months enhanced significantly wool characteristics of Barki ewes (fiber length, fiber diameter, staple strength and clean wool yield).

\section{REFERENCES}

Bird, P. and Moir, R. (1972). Sulphur metabolism and excretion studies in ruminants VIII. Methionine degradation and utilization in sheep when infused into the rumen or abomasum. Australian Journal of Biological Sciences,25(4): 835-848.

Bray, A., Smith, M. and Merrick, N.(1993).Wool growth responses of Romney rams selected for high and low wool strength to nutrient supplementation in winter. In 'Proceedings-New Zealand Society Of Animal Production', pp. 323-323

Brusch, H. (2012). 'Histones and other nuclear proteins.' (Elsevier).

Caffin, R.N. (1980). The CSIRO staple strength/length system. I. Design and performance. J. Text. Inst., 71(2): $65-70$.

Chapman, R.E. (1960). In the biology of the fleece, edited by A. S. Fraser, and B.F. Short, Animal research Laboratories Technical Paper No. 3. CSIRO, Australia.

Corbett, G.G. (1979). The agreement hierarchy. Journal of linguistics, 15(02): 203-224.

Doyle, P. and Bird, P. (1975). The influence of dietary supplements of DL-methionine on the growth rate of wool. Crop and Pasture Science,26(2): 337-342.
Galbraith, H. (2000). Protein and sulphur amino acid nutrition of hair fibre-producing Angora and Cashmere goats. Livestock Production Science,64(1): 81-93.

Gillespie, J., Broad, A. and Reis, P.A. (1969).A further study on the dietary-regulated biosynthesis of high-sulphur wool proteins. Biochemical Journal, 112(1): 41-49.

Graceva, L. (1969). Effect of methionine on intensity of growth of wool in sheep. Ovcevodstvo, 2: 34-35.

Helal, A. (2004).Effect of sulfur supplementation on wool production in barki sheep. Ph. d. Thesis, Fac. Agric., Cairo Univ., Giza, Egypt.

Hynd, P., Edwards, N., Weaver, S., Chenoweth, K., Stobart, R. and Heberle, N. (2015). Biological defleecing: intravenous infusion of amino acid mixtures lacking lysine and methionine creates a weakened zone in the wool staple, which is amenable to mechanical wool harvesting. Animal Production Science,55(10): 12641271.

Pellet,P.L. and Young,V.R. (1980).Nutritional evaluation of protein foods . published by the United Nation University.

Reis, P.J. (1967). The growth and composition of wool IV. The differential response of growth and of sulphur content of wool to the level of sulphur-containing amino acids given per abomasum. Australian Journal of Biological Sciences20(4): 809-826.

Reis, P.J. (1982). Groth and characteristics of wool and hair. In I.E. Coop (Ed.) world animal Science: 2005-223. Elsever Scientific Publishing Co. Amsterdam, Holand.

Reis, P.J. (1989). The influence of absorbed nutrients on wool growth. In the Biology of Wool and Hair. (Eds. G.E. Rogers, P.J. Reis, K.A. Ward and R.C. Marshall) pp.185-203. (Chapman and Hall: London). 
Reis, P.J. (1991). Nutritional regulation of wool growth in Merino sheep. Wool biology'.(Ed. PI Hynd)(AWC).

Reis, P.J. and Tunks, D. (1978). Effects on wool growth of the infusion of mixtures of amino acids into the abomasum of sheep. The Journal of Agricultural Science, $90(01)$ : 173-183.

Reis, P.J., Tunks, D. and Downes, A. (1973). The influence of abomasal and intravenous supplements of sulphurcontaining amino acids on wool growth rate. Australian journal of biological sciences,26(1): 249258.

Reis, P., Tunks, D. and Munro, S. (1990). Effects of the infusion of amino acids into the abomasum of sheep, with emphasis on the relative value of methionine, cysteine and homocysteine for wool growth. The Journal of Agricultural Science,114(01): 59-68.

Rogers, G. (1964). Isolation and properties of inner sheath cells of hair follicles. Experimental cell research,33(1): 264-276.

Sahlu, T. and Fernandez, J. (1992). Effect of intraperitoneal administration of lysine and methionine on mohair yield and quality in Angora goats. Journal of animal science70(10), 3188-3193.

SAS (2008). User's Guide. Statistics.Version 9.2 edition. SAS Institute Inc., Cary, NC.
Stephenson, R. G. A., Suter, G. R. and Howitt, C. J. (1991). Wool growth responses to DL-methionine administration and factors affecting the value of supplementation. Aust. J. Exp. Agric., 31: 471-477.

Storm, E. and Orskov, E. (1984). The nutritive value of rumen micro-organisms in ruminants. 4 . The limiting amino acids of microbial protein in growing sheep determined by a new approach. The British Journal of Nutrition,52(3): 613-620.

Tabor, C.W. and Tabor, H. (1976). 1, 4-Diaminobutane (putrescine), spermidine, and spermine. Annual Review of Biochemistry,45(1): 285-306.

Williams, A., Robards, G. and Saville, D. (1972).Metabolism of Cystine by Merino Sheep Genetically Different in Wool Production II. the Responses in Wool Growth to Abomasal Infusions of L-Cystine or Dl-Methionine. Australian Journal of Biological Sciences,25(6): 1269-1276.

Williams-Ashman, H.G. and Canellakis, Z.N. (1979). Polyamines in mammalian biology and medicine. Perspectives in Biology and Medicine22(3), 421-453

\footnotetext{
تأثير اضافه الليسين أو/ والميثيونين المحمي علي بعض صفات الصوف في الاغنام البرقي

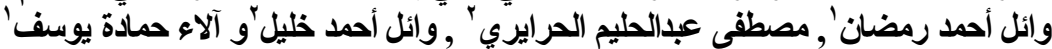

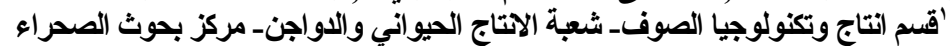

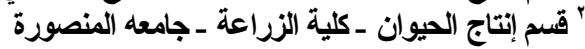

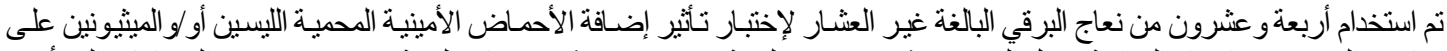

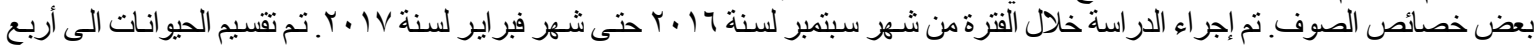

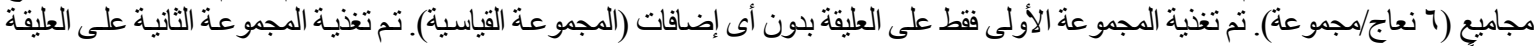

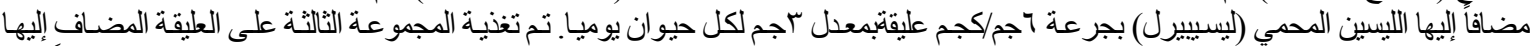

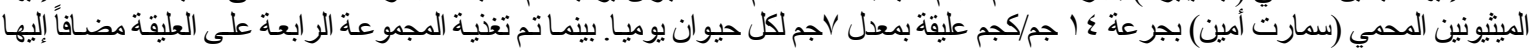

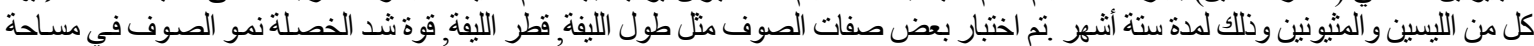

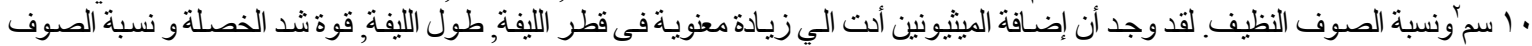

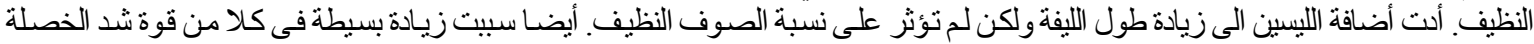

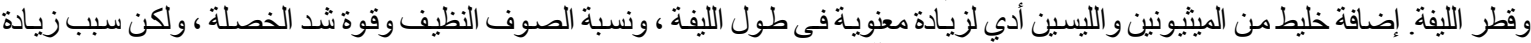

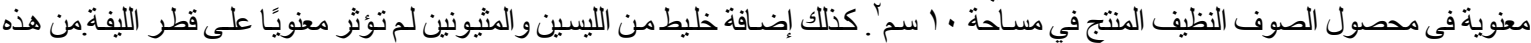

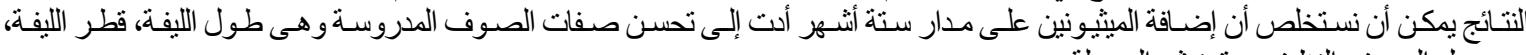
محصول الصوف النظيف، وقوة شد الخصلة.
} 